\title{
Modeling Nitrate Leaching and Optimizing Water and Nitrogen Management under Irrigated Maize in Desert Oases in Northwestern China
}

\author{
Kelin Hu China Agricultural University \\ Yong Li University of Melbourne \\ Weiping Chen Chinese Academy of Sciences \\ Deli Chen, Yongping Wei, and Robert Edis University of Melbourne \\ Baoguo Li* and Yuanfang Huang China Agricultural University \\ Yuanpei Zhang Ningxia Academy of Agricultural and Forestry Sciences
}

Understanding water and $\mathrm{N}$ transport through the soil profile is important for efficient irrigation and nutrient management to minimize nitrate leaching to the groundwater, and to promote agricultural sustainable development in desert oases. In this study, a process-based water and nitrogen management model (WNMM) was used to simulate soil water movement, nitrate transport, and crop growth (maize [Zea mays L.]) under desert oasis conditions in northwestern China. The model was calibrated and validated with a field experiment. The model simulation results showed that about $35 \%$ of total water input and $58 \%$ of the total $\mathrm{N}$ input were leached to $<1.8 \mathrm{~m}$ depth under traditional management practice. Excessive irrigation and $\mathrm{N}$ fertilizer application, high nitrate concentration in the irrigation water, together with the sandy soil texture, resulted in large nitrate leaching. Nitrate leaching was significantly reduced under the improved management practice suggested by farm extension personnel; however, the water and nitrate inputs still far exceeded the crop requirements. More than 1700 scenarios combining various types of irrigation and fertilizer practices were simulated. Quantitative analysis was conducted to obtain the best management practices (BMPs) with simultaneous consideration of crop yield, water use efficiency, fertilizer $\mathrm{N}$ use efficiency, and nitrate leaching. The results indicated that the BMPs under the specific desert oasis conditions are to irrigate the maize with $600 \mathrm{~mm}$ of water in eight times with a single fertilizer application at a rate of $75 \mathrm{~kg} \mathrm{~N} \mathrm{ha}^{-1}$.
Copyright $\odot 2010$ by the American Society of Agronomy, Crop Science Society of America, and Soil Science Society of America. All rights reserved. No part of this periodical may be reproduced or transmitted in any form or by any means, electronic or mechanical, including photocopying, recording, or any information storage and retrieval system, without permission in writing from the publisher.

Published in J. Environ. Qual. 39:667-677 (2010).

doi:10.2134/jeq2009.0204

Published online 26 Jan. 2010.

Received 3 June 2009.

*Corresponding author (libg@cau.edu.cn).

- ASA, CSSA, SSSA

677 S. Segoe Rd., Madison, WI 53711 USA
$\mathrm{R}$ APID ECONOMIC AND POPULATION GROWTH requires agriculture to produce sufficient food to sustain China's development. One of the effective measures is to increase irrigation and fertilizer application (Zhu and Chen, 2002). However, large irrigation and $\mathrm{N}$ fertilizer inputs generally result in low water and $\mathrm{N}$ use efficiency. Growing incidences of nitrate pollution and dramatic increases of groundwater nitrate concentration in intensive farming regions have been reported by many researchers (Zhang et al., 1996; Hu et al., 2005; Ju et al., 2006). This issue has become very serious in desert oases of western China. In the presence of light-textured soils, excessive irrigation (typically as flood irrigation) and fertilizer application have resulted in $\mathrm{NO}_{3}^{-}-\mathrm{N}$ concentrations as high as $130 \mathrm{mg} \mathrm{N} \mathrm{L}^{-1}$ in groundwater accessed in community wells (unpublished data, 2006) in the Left Banner, Alxa League (Inner Mongolia). The incidence of high $\mathrm{NO}_{3}^{-}-\mathrm{N}$ concentrations below the root zone in desert ecosystems has been observed elsewhere (Walvoord et al., 2003).

Various methods have been employed to quantitatively evaluate $\mathrm{N}$ leaching in unsaturated soils. Soil coring is simple, relatively cheap, widely used, and applicable to most soils. However, soil coring is time consuming, destructive, and not suitable for calculating N leaching (Jury and Nielsen, 1989). Ceramic suction cup lysimeters are considered to be a suitable technique to monitor $\mathrm{N}$ leaching in nonstructured soils (Webster et al., 1993). They are easy to install and allow repeated measurements from the same location. However, it is often difficult to obtain adequate sample volumes under low soil water availability and dry conditions that often prevail in coarse sandy soils. Consequentially, the use of ceramic cups may introduce large uncertainties in calculating $\mathrm{N}$ losses (Zotarelli et al., 2007). Nitrogen leaching dynamics may

K. Hu, B. Li, and Y. Huang, Dep. of Soil and Water Sciences, China Agricultural Univ., Beijing 100193, P.R. China; Y. Li, D. Chen, Y. Wei, and R. Edis, Dep. of Resource Management and Geography, Melbourne School of Land and Environment, Univ. of Melbourne, VIC 3010, Australia; W. Chen, State Key Lab. of Urban and Regional Ecology, Research Center for Eco-Environmental Sciences, Chinese Academy of Sciences, Beijing 100085, P.R. China; Y. Zhang, Agricultural Biotechnology Center, Ningxia Academy of Agricultural and Forestry Sciences, Ningxia 750002, P.R. China. Assigned to Associate Editor Richard Zartman.

Abbreviations: BMPs, best management practices; FNUE, fertilizer N use efficiency; LAl, leaf area index; MCs, mini-chambers; NCP, North China Plain; WNMM, water and nitrogen management model; WUE, water use efficiency. 
be studied by drainage lysimeters that can capture the entire leachate volume below a specific soil depth. However, it is often expensive to construct field-scale drainage lysimeters. Nutrients transported through soil profiles may also be investigated by ion exchange resin cores, but it is difficult to create similar conditions for water flow in the boxes as in the surrounding soil (Wilcke and Lilienfein, 2005).

Under field conditions, nitrate leaching is dependent on a number of simultaneous processes such as plant uptake and biotransformations. Thus, it is not possible to accurately evaluate nitrate leaching in soil-water-plant systems in the field based on experimental data alone. To provide BMPs for farmers or policymakers, it is necessary to combine experimental data with computer models.

There are number of computer models such as GLEAMS (Leonard et al., 1987), EPIC (Williams, 1995), NLEAP (Shaffer et al., 1995), LEACHM (Hutson and Wagenet, 1991), APSIM (Asseng et al., 1998), DAISY (Hansen, 2000), RZWQM (Hanson et al., 1999), and DSSAT (Jones et al., 2003) that can be used to evaluate the integrated effects of soil, climate, and management on crop growth and nitrate leaching. In China, the amounts of water and fertilizer input are very high, especially in the North China Plain (NCP) with a wheat (Triticum aestivum L.) and maize double-cropping system. Sometimes, the convection-dispersion equation could not deal with this situation of numerical dispersion or oscillation caused by very high irrigation rate. Recently, $\mathrm{Li}$ et al. (2007) developed a process-based WNMM model. This model can simulate the water, carbon, and $\mathrm{N}$ dynamics, as well as plant growth under various agricultural management practices, specifically for the intensive cropping (wheat-maize) systems in the NCP. The model had been well calibrated and validated for the Chinese agroecosystems (Li et al., 2005, 2007; Sun et al., 2008). In addition, it is very easy to use for realizing the scenario analysis because each input parameter required by the model is organized in individual text files. Computer simulation models can provide a less expensive and effective means to evaluate $\mathrm{N}$ leaching losses under various conditions (Hadas et al., 1999; Shaffer et al., 2001; Ahuja et al., 2002; Ma et al., 2007). The outputs are useful to answer "what if" types of questions. Starting with a reference scenario the worst or best possible cases may be defined.

The objectives of this study are to (i) validate and apply the WNMM model to simulate the water movement, $\mathrm{N}$ fate, and (ii) optimize the water and $\mathrm{N}$ management in a desert oasis.

\section{Materials and Methods}

\section{Study Area}

The study area is located in Left Banner, western Inner Mongolia, China $\left(37^{\circ} 24^{\prime}-41^{\circ} 52^{\prime} \mathrm{N}, 103^{\circ} 21^{\prime}-106^{\circ} 51^{\prime}\right.$ E) (Fig. 1). The elevation in this region ranges from 800 to $1500 \mathrm{~m}$. Desert accounts for approximately $42 \%$ of the region's area, 80,400 $\mathrm{km}^{2}$. The soils are alluvial mixed with gray desert soils. The region is classified as a warm-temperate desert arid zone with a continental climate. The average annual precipitation is 116

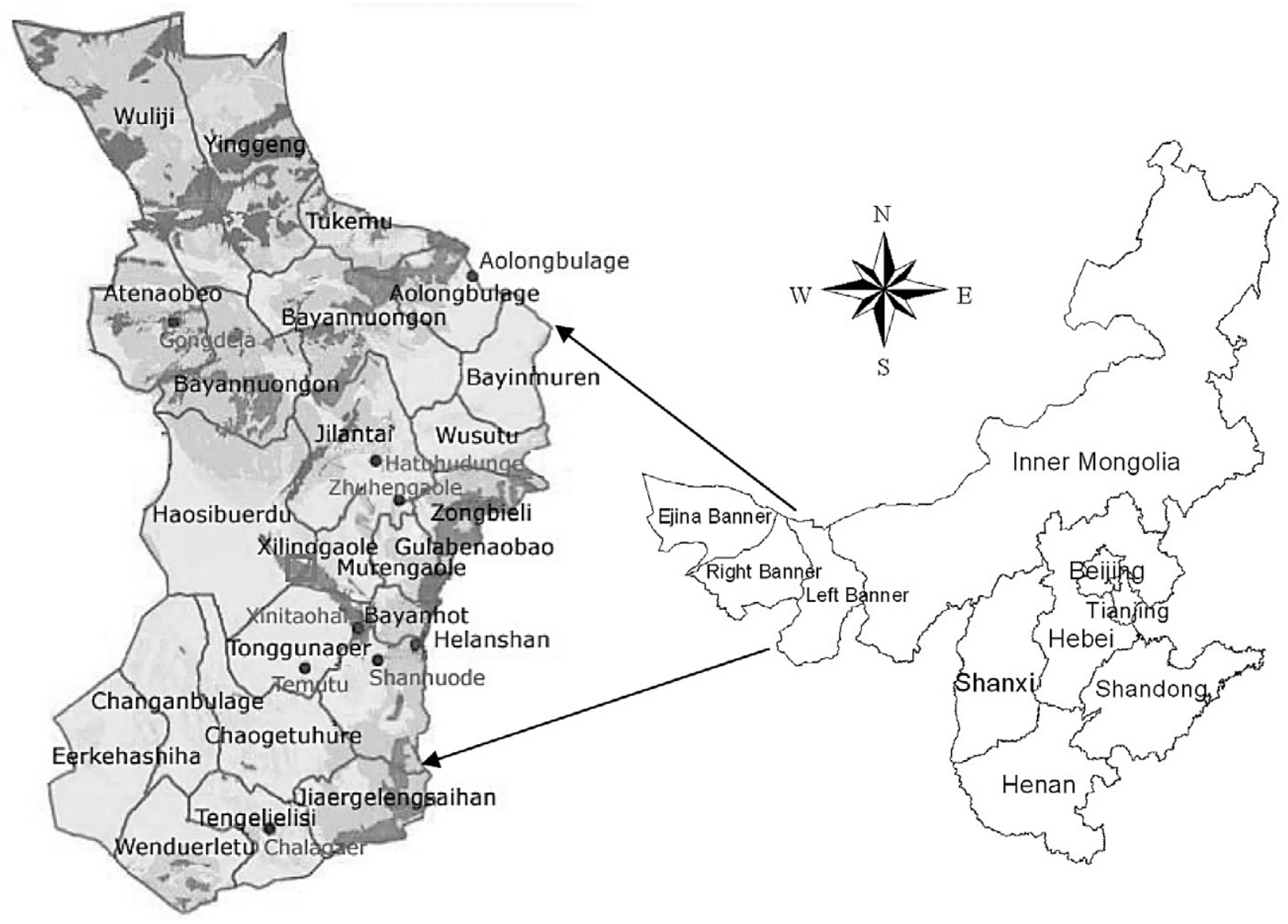

Fig. 1. Location of the study area in Alxa League, Inner Mongolia, northwestern China. 
Table 1. Soil physical-chemical properties for soil profile in Alxa League, Inner Mongolia, northwestern China.

\begin{tabular}{|c|c|c|c|c|c|c|c|c|c|c|c|c|}
\hline \multirow{2}{*}{ Soil layer } & \multicolumn{3}{|c|}{ Particle fraction } & \multirow{2}{*}{$\begin{array}{l}\text { Texture } \\
\text { (USA) }\end{array}$} & \multirow{2}{*}{$\mathrm{pH}^{+}$} & \multirow{2}{*}{$\mathrm{OM}^{\ddagger}$} & \multirow{2}{*}{ TN } & \multirow{2}{*}{ TP } & \multirow{2}{*}{ TK } & \multirow{2}{*}{ AN } & \multirow{2}{*}{ AP } & \multirow{2}{*}{ AK } \\
\hline & Sand & Silt & Clay & & & & & & & & & \\
\hline $\mathrm{cm}$ & \multicolumn{3}{|c|}{ - $\%$} & & & \multicolumn{4}{|c|}{$\longrightarrow \mathrm{g} \mathrm{kg}^{-1}$} & \multicolumn{3}{|c|}{$\longrightarrow \mathrm{mg} \mathrm{kg}^{-1}$} \\
\hline $0-35$ & 31.4 & 66.5 & 2.1 & Silt loam & 8.63 & 1.19 & 0.08 & 0.18 & 21.4 & 4 & 2.9 & 30 \\
\hline $35-47$ & 62.8 & 36.2 & 1.0 & Sandy loam & 7.95 & 18.80 & 1.08 & 0.56 & 27.4 & 33 & 3.2 & 116 \\
\hline $47-63$ & 28.6 & 69.0 & 2.4 & Silt loam & 8.05 & 11.90 & 0.60 & 0.50 & 23.6 & 24 & 3.0 & 54 \\
\hline $63-70$ & 78.8 & 19.9 & 1.3 & Loamy sand & 8.33 & 3.58 & 0.24 & 0.42 & 22.5 & 14 & 2.5 & 32 \\
\hline $70-80$ & 10.1 & 85.0 & 4.9 & Silt & 8.48 & 3.13 & 0.16 & 0.22 & 29.8 & 14 & 3.5 & 24 \\
\hline $80-85$ & 83.4 & 15.5 & 1.1 & Loamy sand & 8.35 & 12.60 & 0.86 & 0.69 & 32.0 & 23 & 7.8 & 134 \\
\hline $85-97$ & 13.0 & 82.4 & 4.6 & Silt & 8.87 & 1.72 & 0.08 & 0.17 & 31.0 & 10 & 3.0 & 18 \\
\hline $97-140$ & 74.3 & 24.9 & 0.9 & Loamy sand & 8.24 & 12.80 & 0.82 & 0.60 & 31.4 & 15 & 6.7 & 110 \\
\hline $140-200$ & 89.8 & 9.4 & 0.9 & Sand & 8.80 & 2.43 & 0.18 & 0.34 & 25.3 & 10 & 4.2 & 36 \\
\hline
\end{tabular}

$+\mathrm{pH}$, under soil:water of 1:2.5.

₹ OM, organic matter; TN, total nitrogen; TP, total phosphorus; TK, total potassium; AN, available nitrogen; AP, available phosphorus; AK, available potassium.

$\mathrm{mm}$, of which 70 to $80 \%$ is concentrated during the summer season (June to September). Total annual potential evaporation reaches $3005 \mathrm{~mm}$, which is 20 times greater than the annual precipitation. The annual average temperature is $8.3^{\circ} \mathrm{C}$ and the average growing degree-days for the area is 184 . The groundwater depth is about 40 to $70 \mathrm{~m}$. There are about 20,000 ha of irrigated cropping reliant on groundwater extraction in 10 major oases. The oasis cropping system is a single crop produced annually from the middle of April to early October. The main crops are maize and spring wheat, which comprise $80 \%$ of the cropped area. The irrigation amounts range from 800 to $1700 \mathrm{~mm}$, typically as flood irrigation. Typical $\mathrm{N}$ fertilizer application rates are about $250 \mathrm{~kg} \mathrm{~N} \mathrm{ha}^{-1}$.

\section{Field Experiment}

The experimental site was located in the mid-south of the Chahantan oasis (denoted by a rectangle in Fig. 1). A soil profile pit was excavated to $2.0 \mathrm{~m}$ and samples of soil textural layers were collected for analysis of basic physicochemical properties (Table 1). The soil was classified as Aquic Cambisol. The data illustrated that the available nutrients in the surface layer were low, most probably due to excessive irrigation or crop uptake.

Maize was planted on 15 April and harvested on 26 Sept. 2005. Plant density was approximately 60,000 plants ha ${ }^{-1}$. There were two irrigation and fertilizer treatments: traditional management practice (T1) and improved management practice (T2). The plot size was 20 by $20 \mathrm{~m}$, with five replicates. For the traditional practice, the plots received $165 \mathrm{~mm}$ water $\mathrm{d}^{-1}$ for each of five irrigation events, based on the common practice used by the local farmers. For the improved management practice, the plots received $105,135,135,135$, and $120 \mathrm{~mm}$ water $\mathrm{d}^{-1}$ for the five irrigation events, respectively, based on the suggestion from local farm experts. The irrigations occurred on Days 55, 73, 93, 118, and 142 after the planting. The average $\mathrm{NO}_{3}-\mathrm{N}$ concentration of the irrigation water was $28.5 \mathrm{mg} \mathrm{N}$ $\mathrm{L}^{-1}$. Diammonium phosphate at $225 \mathrm{~kg} \mathrm{ha}^{-1}$ was applied as a base fertilizer $\left(40.5 \mathrm{~kg} \mathrm{~N} \mathrm{ha}^{-1}\right)$. Urea was surface-applied at the first irrigation for both treatments at a rate of $138 \mathrm{~kg} \mathrm{~N}$ $\mathrm{ha}^{-1}$, and irrigation immediately after urea application. Since the $\mathrm{N}$ input from irrigation under Treatment $\mathrm{T} 2$ was less than that under Treatment T1 (the irrigation water contains high concentration of nitrate), additional urea (at a rate of $138 \mathrm{~kg}$ $\mathrm{N} \mathrm{ha}^{-1}$ ) was applied at the third irrigation for Treatment T2.

In each plot, the soil volumetric water content was measured every $7 \mathrm{~d}$ using time-domain reflectometry probes (TRIME-IPH, IMKO, Ettlingen, Germany) at $10-\mathrm{cm}$ intervals through $180 \mathrm{~cm}$ of soil profile. Soil samples from depths of $0-35,35-47,47-63,63-70,70-80,80-85,85-97,97-140$, and 140-180 cm were collected at four times: before sowing, on Days 82 and 117 after planting, and at harvest. Each fresh soil sample was extracted with $2 \mathrm{~mol} \mathrm{~L}^{-1} \mathrm{KCl}$ to determine the concentrations of $\mathrm{NH}_{4}-\mathrm{N}$ and $\mathrm{NO}_{3}-\mathrm{N}$ using a continuous flow analyzer (TRAACS 2000, Bran and Luebbe, Norderstedt, Germany). Before sowing and at harvest, available phosphorus (Olsen $\mathrm{P}$ ) was extracted with $0.5 \mathrm{~mol} \mathrm{~L}^{-1} \mathrm{NaHCO}_{3}$ at $\mathrm{pH} 8.5$ and using colorimetry and ascorbic acid-ammonium molybdate reagents. Available potassium was extracted with $1 \mathrm{~mol}$ $\mathrm{L}^{-1} \mathrm{NH}_{4} \mathrm{OAC}$ at $\mathrm{pH} 7$ and using atomic absorption spectrophotometry for each soil sample. Static mini-chambers (MCs) were employed to sample gaseous $\mathrm{N}_{2} \mathrm{O}$ emissions (only measured in $1 \mathrm{wk}$ after the first fertilizer application). Five clusters of five MCs $(25 \mathrm{MCs})$ were distributed through the two treatments (total 50 MCs). Gas samples were analyzed for $\mathrm{N}_{2} \mathrm{O}$ concentration by gas chromatography with a ${ }^{63} \mathrm{Ni}$ electron capture detector at the University of Melbourne.

Crop height was recorded at the key plant development stages, and two random groups of three plants were sampled from each plot on Days 82 and 117 after planting, and at harvest. The plant samples were separated into root, stem, leaf, tassel, and cob. Dry weights and N contents of all parts were determined. Leaf area index (LAI), root depth, and density were also measured. At harvest, the cobs from all plots were harvested, oven-dried at $70^{\circ} \mathrm{C}$ for $24 \mathrm{~h}$, and weighed to estimate yield.

\section{Model Description}

Nitrate leaching under various agricultural management practices was simulated by the WNMM model (Li et al., 2007). The model integrates the key processes governing the water movement and $\mathrm{N}$ cycle in the soil-crop system, including evapotranspiration, canopy interception, water movement, groundwater fluctuations, heat flow, solute transport, mineralization of fresh 
crop residue and soil organic $\mathrm{N}$, formation of soil organic $\mathrm{N}$, immobilization in biomass, nitrification, ammonia volatilization, denitrification, and nitrous oxide emissions.

In the model, the potential evapotranspiration referenced for 40-cm-high alfalfa (Medicago sativa L.) was estimated using the Penman-Monteith method (Allen et al., 1998). Soil evaporation and plant transpiration were predicted separately by considering ground cover, LAI, and crop root density distribution in the soil profile. Dynamic soil water content and flux were calculated by a numeric solution of a simple tippingbucket water balance model (Scotter et al., 1979). The root water uptake is simulated by the van Genuchten (1987) model considering the water stress response function. Nitrate, ammonium, and urea transport were governed by an empirical solute transport equation adopted in the EPIC model (Williams, 1995). Daily average soil temperatures with depth were estimated using the empirical equation of Arnold et al. (1993). The crop growth module was a simplification of the EPIC crop model, which applies the concepts of phenological crop development based on daily accumulated heat units, harvest index for partitioning grain yield, Monteith's approach for potential biomass, and stress adjustments for water, temperature, and $\mathrm{N}$ availability in root zone of the soil profile. It predicts total crop dry matter, LAI, root depth and density distribution, harvest index, crop yield, and $\mathrm{N}$ uptake. The model runs on a daily time step and is driven by variables of meteorological and crop biological data.

\section{Model Parameters}

Literature values and data from specially designed experiments were employed to define the parameters needed for the model simulations, summarized as follows:

Initial Conditions. The initial volumetric water contents and concentrations of $\mathrm{NO}_{3}-\mathrm{N}$ along the soil profile were set based on field measurements made before maize planting. The initial soil volumetric water contents for the nine soil textural layers were $0.20,0.23,0.24,0.21,0.20,0.15$, $0.12,0.13$, and $0.09 \mathrm{~cm}^{3} \mathrm{~cm}^{-3}$, respectively. The initial mineral $\mathrm{N}$ concentrations at the nine soil textural layers were set based on values given in Table 1 for available $\mathrm{N}$.

Boundary Conditions. Surface runoff was neglected in the model simulation because the study site is flat. A potential soil evaporation or water infiltration controlled boundary was used for the surface (Li et al., 2007). The lower boundary was set as free drainage given that the groundwater depth is $>50 \mathrm{~m}$.

Soil Hydraulic Properties. The residual water content $\left(\theta_{\mathrm{r}}\right)$, saturated water content $\left(\theta_{s}\right)$, field capacity $(\mathrm{FC})$, wilting point water content $(\theta \mathrm{wp})$, and saturated hydraulic conductivity $(K)$ for each layer in the soil profile are summarized in Table 2 . These data were adjusted based on measured data during the calibration of the model.

Meteorological Data. Meteorological data including radiation, and minimum and maximum temperatures are necessary for modeling evapotranspiration and crop development. These data were obtained from the Gilantai weather station, which is $45 \mathrm{~km}$ away from the study area. Rainfall was measured locally.

Crop Development Parameters. The crop development-related parameters were set based on those of Zhang et al. (2002) and $\mathrm{Hu}$ et al. (2008). The maximum crop height was set to $2.5 \mathrm{~m}$. Maximum crop root depth was set to $1.5 \mathrm{~m}$. The optimal and minimum temperatures for crop development were set to 25 and $8^{\circ} \mathrm{C}$, respectively. The accumulated effective temperature for maize from emergence to maturity was set to $1690^{\circ} \mathrm{C}$. The photosynthetic active radiation at the top of the canopy was set to $0.48 \mathrm{~J} \mathrm{~m}^{-2} \mathrm{~s}^{-1}$. Normal $\mathrm{N}$ fractions in crop biomass at emergence, at $50 \%$ maturity, and at full maturity were set to $0.045,0.015$, and $0.01 \mathrm{~kg} \mathrm{~N} \mathrm{~kg}^{-1}$ biomass, respectively. The harvest index was set to 0.50 . Maximal and residual crop LAIs were set to 6.0 and 0.5 . Crop root uptake $\mathrm{NH}_{4}-\mathrm{N}$ and $\mathrm{NO}_{3}-\mathrm{N}$ coefficients were both set to 0.50 .

Dispersivity and Diffusion Coefficients. The molecular diffusion coefficient of nitrate in free water was set to $1.2 \mathrm{~cm}^{2} \mathrm{~d}^{-1}$. The longitudinal dispersivity was set based on soil texture, and varied from 2 to $15 \mathrm{~cm}$ along the soil profile ( $\mathrm{Hu}$ et al., 2008).

Carbon and Nitrogen Transformations. The rate constants for mineralization, immobilization, volatilization, and denitrification of $\mathrm{N}$ needed to be specified for $\mathrm{N}$ transformations. Data from Li et al. (2007) were used to define these $\mathrm{N}$ transformation rates (Table 3).

\section{Simulation Scenarios}

To optimize the water and fertilizer management, 1700 numerical simulations were conducted to simulate the effect of irrigation and fertilizer practice on crop yield, nitrate leaching, water drainage, and water use efficiency (WUE) under the following scenarios:

1. Varying the total irrigation inputs from 300 to $900 \mathrm{~mm}$ in increments of $60 \mathrm{~mm}$;

2. Varying number of irrigation events from three to 11 ;

Table 2. Soil hydraulic properties in soil profile in the Chahantan oasis in Alxa League, Inner Mongolia, northwestern China.

\begin{tabular}{|c|c|c|c|c|c|c|c|c|c|}
\hline \multirow{2}{*}{ Property $†$} & \multicolumn{9}{|c|}{ Soil layer } \\
\hline & $0-35$ & $35-47$ & $47-63$ & $63-70$ & $70-80$ & $80-85$ & $85-97$ & $97-140$ & $140-200$ \\
\hline & & & & & $-\mathrm{cm}-$ & & & 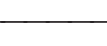 & - \\
\hline$\theta_{r}\left(\mathrm{~cm}^{3} \mathrm{~cm}^{-3}\right)$ & 0.041 & 0.065 & 0.079 & 0.078 & 0.089 & 0.071 & 0.079 & 0.075 & 0.082 \\
\hline$\theta_{\mathrm{s}}\left(\mathrm{cm}^{3} \mathrm{~cm}^{-3}\right)$ & 0.30 & 0.33 & 0.32 & 0.27 & 0.25 & 0.24 & 0.21 & 0.21 & 0.20 \\
\hline $\mathrm{FC}\left(\mathrm{cm}^{3} \mathrm{~cm}^{-3}\right)$ & 0.236 & 0.27 & 0.25 & 0.22 & 0.21 & 0.18 & 0.15 & 0.19 & 0.165 \\
\hline$\theta w p\left(\mathrm{~cm}^{3} \mathrm{~cm}^{-3}\right)$ & 0.05 & 0.12 & 0.11 & 0.10 & 0.12 & 0.13 & 0.10 & 0.11 & 0.12 \\
\hline$K_{\mathrm{s}}\left(\mathrm{cm} \mathrm{d}^{-1}\right)$ & 62.8 & 68.3 & 50.7 & 89.3 & 52.8 & 112.6 & 36.8 & 66.1 & 45.4 \\
\hline
\end{tabular}

$+\theta_{\mathrm{r}^{\prime}}$ residual water content; $\theta_{\mathrm{s}^{\prime}}$ saturated water content; $\mathrm{FC}$, field capacity; $\theta \mathrm{wp}$, wilting point water content; $K_{\mathrm{s}^{\prime}}$ saturated hydraulic conductivity. 


\begin{tabular}{|c|c|c|}
\hline Parameters & Description & Value \\
\hline C_Residue_p0 & Rapidly decomposed fraction of fresh organic C (0-1) & 0.8 \\
\hline C_Residue_p1 & Resistantly decomposed fraction of fresh organic C (0-1) & 0.2 \\
\hline C_fCactive & Fraction of active soil organic carbon (SOC) in SOC (0-1) & 0.40 \\
\hline C_fCmb & Fraction of microbial biomass in SOC (0-1) & 0.04 \\
\hline C_CR_residue 0 & Rate constant for rapidly decomposed fresh organic $C\left(d^{-1}\right)$ & 0.2 \\
\hline C_CR_residue1 & Rate constant for resistantly decomposed fresh organic $\mathrm{C}\left(\mathrm{d}^{-1}\right)$ & 0.05 \\
\hline C_CR_MB_alive & Decay rate for alive microbial biomass $C$ pool $\left(\mathrm{d}^{-1}\right)$ & 0.002 \\
\hline C_CR_MB_dead & Decay rate for dead microbial biomass $C$ pool $\left(\mathrm{d}^{-1}\right)$ & 0.05 \\
\hline C_CR_active & Rate constant for active $\mathrm{SOC}$ pool $\left(\mathrm{d}^{-1}\right)$ & 0.003 \\
\hline C_CR_passive & Rate constant for passive SOC pool $\left(\mathrm{d}^{-1}\right)$ & $1 \mathrm{E}^{-05}$ \\
\hline C_fFoc0 & Microbial use efficiency of rapidly decomposed fresh organic C (0-1) & 0.85 \\
\hline C_fFoc1 & Microbial use efficiency of resistantly decomposed fresh organic $C(0-1)$ & 0.50 \\
\hline N_CR_nh3 & Rate constant for $\mathrm{NH}_{3}$ volatilization $\left(\mathrm{d}^{-1}\right)$ & 0.01 \\
\hline N_CR_nit & Rate constant for nitrification $\left(\mathrm{d}^{-1}\right)$ & 0.175 \\
\hline N_CR_den & Rate constant for denitrification $\left(\mathrm{d}^{-1}\right)$ & 0.015 \\
\hline NO3_Leach_Coeff & Leaching coefficient for nitrate (0-1) & 0.85 \\
\hline NH4_Leach_Coeff & Leaching coefficient for ammonium (0-1) & 0.05 \\
\hline UREA_Leach_Coeff & Leaching coefficient for urea (0-1) & 0.1 \\
\hline
\end{tabular}

3. Varying total fertilizer application inputs from 75 to 300 $\mathrm{kg} \mathrm{N} \mathrm{ha}{ }^{-1}$ in increments of $15 \mathrm{~kg} \mathrm{~N} \mathrm{ha}^{-1}$;

4. Varying the number of fertilizer application events from one to four.

The maximal irrigation rate was set to $160 \mathrm{~mm} \mathrm{~d}^{-1}$ and the minimal rate is set to $60 \mathrm{~mm} \mathrm{~d}^{-1}$, with the same interval between sowing and harvest. The fertilizer application dates are $0,55,93$, and $126 \mathrm{~d}$ after planting, which corresponded with the key stages of the maize growth: sowing, jointing, heading, and grain-filling. The number of scenarios for water and fertilizer inputs are 68 and 25 respectively, so the total number of scenarios combining variable amount and number of times of water and fertilizer practices is 1700 . The scenarios described above were conducted by varying the abovementioned parameters one at a time while holding the values of the other parameters at the default levels.

\section{Results and Discussion}

\section{Model Calibration and Validation}

For both treatments (T1 and T2), the soil water contents and mineral $\mathrm{N}$ concentrations through the soil profile were measured during the maize growth period. Data from Treatment T1 were used to calibrate the model. Soil $\mathrm{N}$ transformation parameters were adjusted by comparing the simulated and measured data. Data from Treatment T2 were then used to validate the model. Figures 2 and 3 illustrate the measured and predicted soil water content and mineral $\mathrm{N}$ concentrations for Treatment T2 at each depth. In general, the simulated data corresponded well with the measured results.

The correlations between measured and simulated volumetric water contents and nitrate concentrations at all observed depths and times under Treatment T2 are shown in Fig. 4. The linear regression correlation coefficients $(r)$ for volumetric water content and nitrate concentration were 0.472 and 0.856 , respectively. Both of them are highly significant $(P<0.001)$. The slopes of the regressions for volumetric water contents and nitrate concentrations were 1.084 and 1.077 , respectively, which are close to the value of 1 .

The root mean square error (RMSE) of the simulated volumetric water contents decreased from 0.084 in the topsoil to 0.013 in deeper soil depths, with an average of 0.035 . For the simulated nitrate concentrations, the RMSEs were 7.09, $8.36,7.87,4.76,2.87$, and 1.41 , respectively, for the depths of $0-10,15-25,35-45,75-85,125-135$, and $165-170 \mathrm{~cm}$. Their index of agreement (Willmott, 1981) ranged from 0.36 to 0.81 . These results showed that the model performed reasonably well in predicting soil water contents and nitrate concentrations in the study area.

In addition, the predicted LAI, total dry matter, and crop $\mathrm{N}$ uptake at various crop stages were similar to the field measurements (Fig. 5). The predicted average crop yields for Treatments $\mathrm{T} 1$ and $\mathrm{T} 2$ were 11,560 and $12,127 \mathrm{~kg} \mathrm{~N} \mathrm{ha}^{-1}$, respectively, and also close to the measurements (Table 4). The tested results indicated that the WNMM model was suitable for simulating water movement, $\mathrm{N}$ cycle, and plant growth under various agricultural management practices in the study area.

\section{Dynamic of Water Drainage and Nitrate Leaching}

During the early crop growth stage, the average monthly temperature was only $12.8^{\circ} \mathrm{C}$. The emergence and growth of maize was very slow, so that crop demand for water and nutrient was low. As a result, a large amount of water drainage and nitrate leaching occurred (Fig. 6). Under Treatment T1, the water drainage was $77 \mathrm{~mm}$ and $108 \mathrm{~mm}$, respectively, for the first two irrigations, accounting for $57.3 \%$ of the total water drainage. Under Treatment T2, the water drainage was $23 \mathrm{~mm}$ and $81 \mathrm{~mm}$, respectively, for the first two irrigations, accounting for $64.6 \%$ of the total water drainage. The amount of nitrate leaching is closely related to drainage. Nitrate leaching during the first two irrigations accounted for 77.2 and $77.6 \%$ of the total nitrate leached for Treatments T1 and T2, respectively. After the early-development stage, the maize grew very quickly, such that LAI increased from 1.3 to 3.2 during $15 \mathrm{~d}$, and the roots reached to $0.6 \mathrm{~m}$. The 


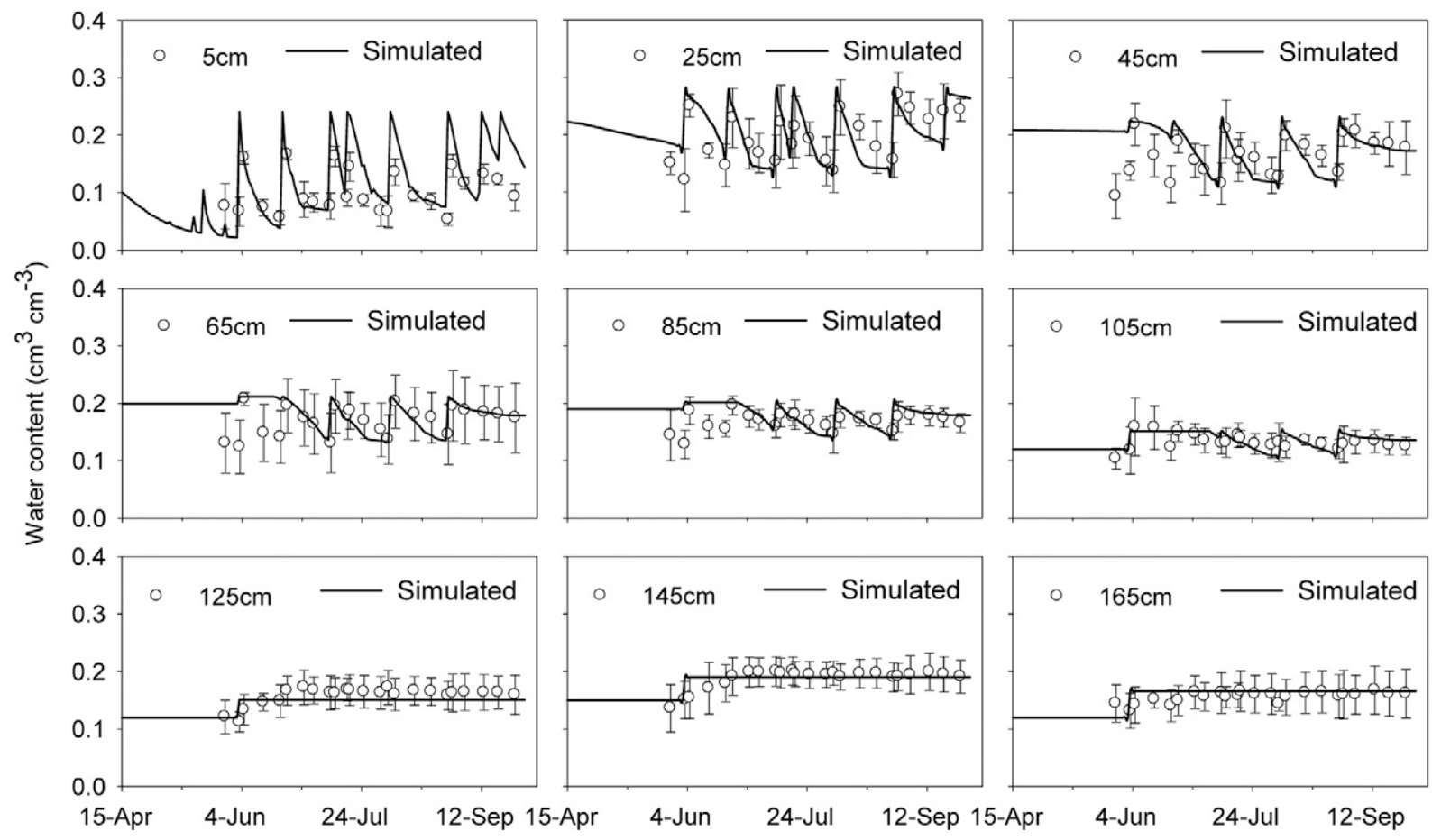

Fig. 2. Comparison of simulated (solid lines) and measured (points) soil volumetric water content $\left(\mathrm{cm}^{3} \mathrm{~cm}^{-3}\right)$ at observed depths under the improved management practice (T2) in 2005.
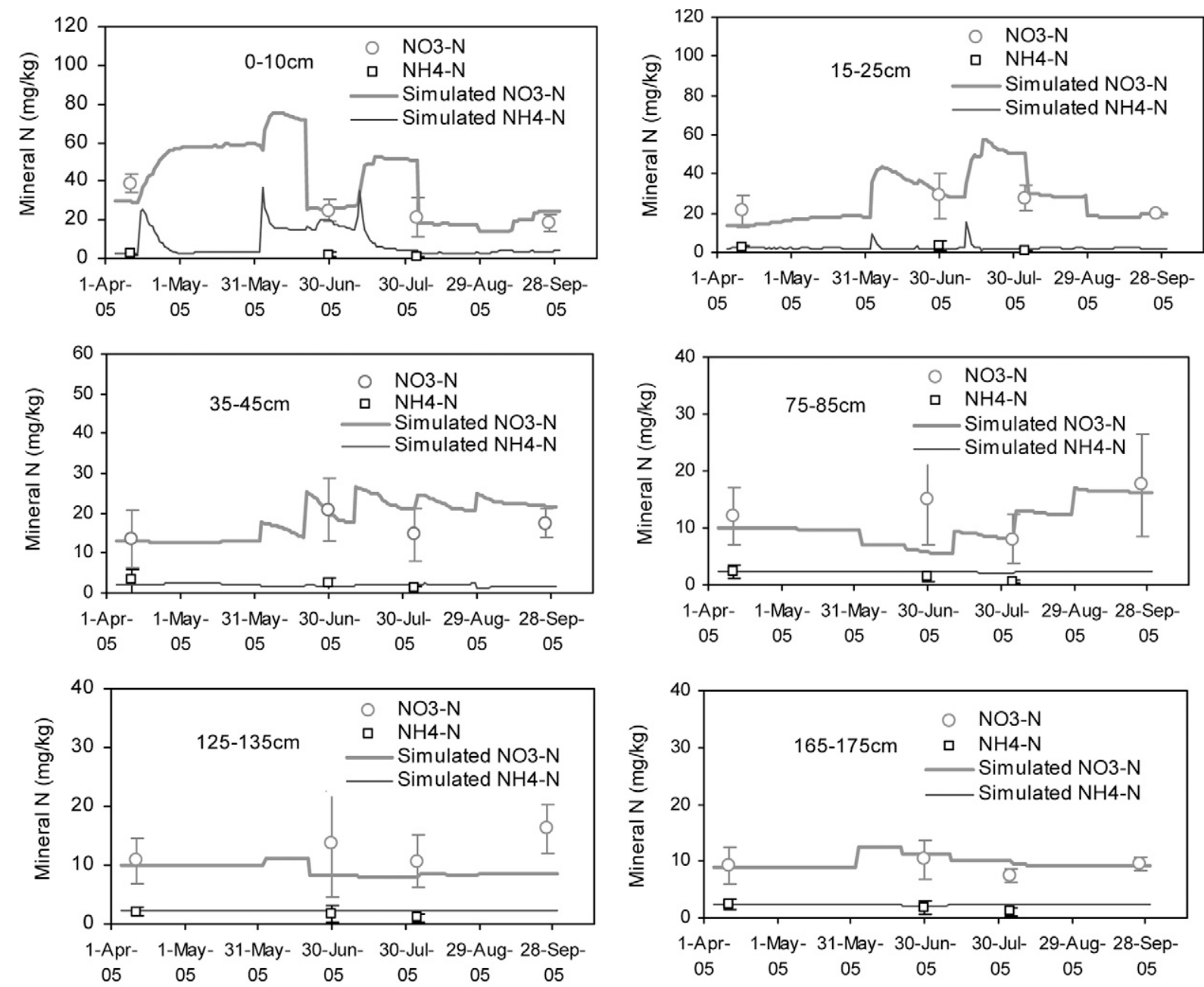

Fig. 3. Comparison of measured (points) and simulated (solid lines) soil mineral nitrogen concentration ( $\mathrm{mg} \mathrm{kg}^{-1}$ ) at observed depths under the improved management practice (T2). 

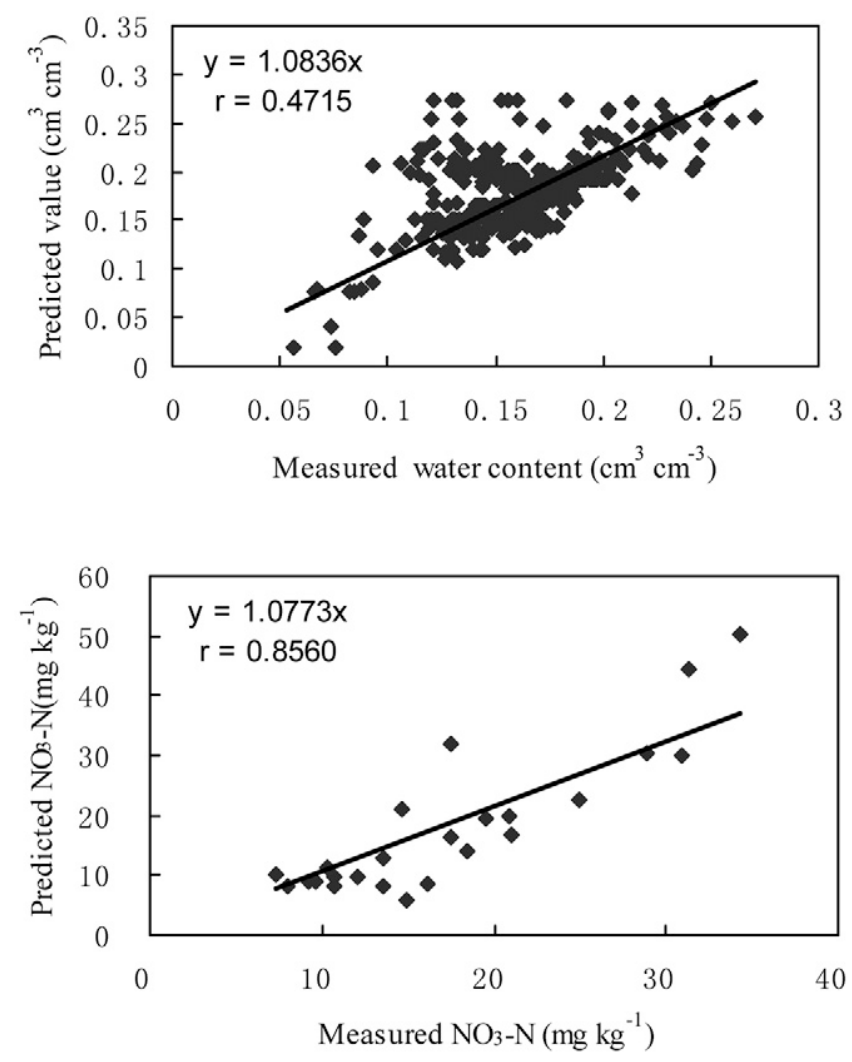

Fig. 4. The relationship between measured and simulated soil volumetric water content $\left(\mathrm{cm}^{3} \mathrm{~cm}^{-3}\right)$ and nitrate concentration $\left(\mathrm{mg} \mathrm{kg}^{-1}\right)$ under the improved management practice (T2).

demand for water and nutrients was relatively high and, as a result, the water drainage and the nitrate leaching were very low.

\section{Water and Nitrogen Balance}

The water balances under Treatments T1 and T2 are summarized in Table 4. During the 174-d plant growth period, precipitation was only $97.5 \mathrm{~mm}$. The main water loss was evapotranspiration, which was 583 and $552 \mathrm{~mm}$ for Treatments $\mathrm{T} 1$ and T2, respectively. The drainage factor was 35 and $22 \%$ for Treatments T1 and T2, respectively. In this region the soil is sandy, with high saturated hydraulic conductivity $\left(K_{s}\right)$. The drainage factor was greater than that found in other areas of China (Zhu and Chen, 2002; Mack et al., 2005; Li et al., 2007; Sun et al., 2008).

Under the improved management practice (T2), the yield and WUE were slightly higher than under the traditional management practice (T1), but not significantly different $(P>$ 0.05; Table 4).
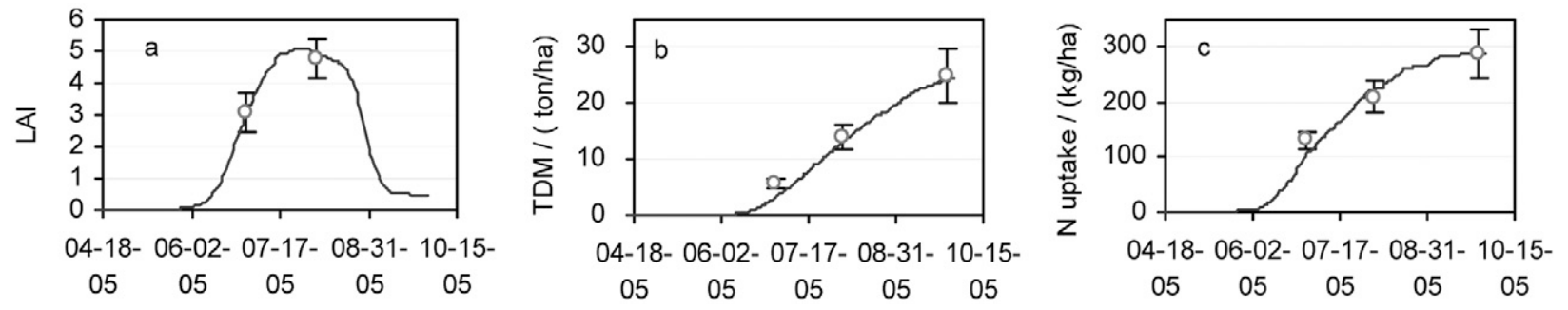

Fig. 5. Comparison of measured and simulated (a) leaf area index (LAl), (b) total dry matter (TDM; kg ha-1), and (c) crop nitrogen uptake (kg N ha ${ }^{-1}$ ) in a desert oasis under the improved management practice (T2).

Hu et al.: Modeling Water and Nitrogen Transport in Desert Oases in China (T1) and improved management practice (T2).

† Drainage factor $=$ Drainage/Total water input.

‡WUE, water use efficiency $=$ Yield/ETa.

The $\mathrm{N}$ balances under Treatments $\mathrm{T} 1$ and $\mathrm{T} 2$ are summarized in Table 5. The $\mathrm{N}$ inputs are from three sources: atmospheric deposition, irrigation, and fertilizer application. The total $\mathrm{N}$ inputs were 442 and $525 \mathrm{~kg} \mathrm{~N} \mathrm{ha}^{-1}$, respectively, for Treatments T1 and T2. The atmospheric deposition (dry and wet) was $28 \mathrm{~kg} \mathrm{~N} \mathrm{ha}^{-1}$ for the study field, accounting for about $6 \%$ of the total $\mathrm{N}$ input. Due to the high nitrate concentration in the groundwater, irrigation made a significant $\mathrm{N}$ contribution, accounting for 53 and $34 \%$ of the total $\mathrm{N}$ input for Treatments $\mathrm{T} 1$ and $\mathrm{T} 2$, respectively.

The majority of the $\mathrm{N}$ outputs were due to plant uptake, with 290 and $273 \mathrm{~kg} \mathrm{~N} \mathrm{ha}^{-1}$ for Treatments T1 and T2, respectively. The $\mathrm{N}$ losses through ammonia volatilization and denitrification were negligible at $<5 \%$ of the $\mathrm{N}$ inputs. These losses are far below those observed for croplands under maize cropping on loam soil in the NCP (Cai et al., 2002; Zhang et al., 2004). Li et al. (2007) studied the volatilization losses caused by different application methods and found the loss associated with surface-broadcast could be greatly reduced by follow-up irrigation. Other studies also found that $\mathrm{N}$ loss by denitrification can be negligible in the NCP (Zhang et al., 2004; Fang et al., 2008). Our results agreed with those reports. However, the nitrate leaching was much greater than those observed for croplands in the NCP (Zhu and Chen, 2002; Mack et al., 2005; Sun et al., 2008; Fang et al., 2008). Under the traditional management practice the total nitrate leaching was as high as 255 $\mathrm{kg} \mathrm{N} \mathrm{ha}{ }^{-1}$, accounting for $58 \%$ of the total $\mathrm{N}$ inputs. Such high nitrate leaching may be attributed to the sandy soil texture, high nitrate concentration in the irrigation water (average nitrate concentration was $28.5 \mathrm{mg} \mathrm{N} \mathrm{L}^{-1}$ ), as well as the high irrigation rate during the early-development stage. Under the improved management practice the $\mathrm{N}$ fertilizer input was higher, but the nitrate leaching was much smaller. The total
Table 4. Water balance under the traditional management practice

\begin{tabular}{lccc}
\hline & \multirow{2}{*}{ Water flux } & \multicolumn{2}{c}{ Treatment } \\
\cline { 3 - 4 } & & T1 & T2 \\
\hline Input $(\mathrm{mm})$ & Irrigation & 825 & 630 \\
& Precipitation & 97.5 & 97.5 \\
Output $(\mathrm{mm})$ & Evapotranspiration $(\mathrm{ETa})$ & 583 & 552 \\
& Drainage & 322 & 161 \\
Balance $(\mathrm{mm})$ & 17.4 & 14.4 \\
Drainage factort & $35 \%$ & $22 \%$ \\
Measured yield $\left(\mathrm{kg} \mathrm{ha}^{-1}\right)$ & 11,606 & 12,209 \\
WUE $\left(\mathrm{kg} \mathrm{ha}^{-1} \mathrm{~mm}^{-1}\right)$ & 20 & 22 \\
\hline
\end{tabular}

Hu et al.: Modeling Water and Nitrogen Transport in Desert Oases in China 
nitrate leaching was $116 \mathrm{~kg} \mathrm{~N} \mathrm{ha}^{-1}$, or about $21 \%$ of the total $\mathrm{N}$ inputs. The results for nitrate leaching agreed with other reports on sandy soils (Sogbedji et al., 2000; Cameira et al., 2003; Gehl et al., 2005; Zotarelli et al., 2007).

\section{Optimizing the Water and Nitrogen Management}

The simulation results indicated that the water and nitrate inputs under Treatments T1 and T2 far exceeded the crop requirements. To reduce the nitrate leaching risk and to preserve water and fertilizer resources, it is imperative to optimize the water and fertilizer application to match crop requirements. Figures 7 and 8 summarize the simulation results from the designed scenarios combining various water and fertilizer practices.

The fitted relationship between crop yield and irrigation amount could be described by a linear with plateau model $\left(R^{2}=0.710^{* *}, n=1700\right)$ given by:

$$
\begin{cases}Y=24.87 I+1011 & I<646 \mathrm{~mm} \\ Y=17,097 & I \geq 646 \mathrm{~mm}\end{cases}
$$

where $Y$ represents the crop yield $\left(\mathrm{kg} \mathrm{ha}^{-1}\right)$ and $I$ represents the amount of irrigation $(\mathrm{mm})$. The crop yield increases linearly with the amount of irrigation and reaches the maximum when the amount of irrigation is $>646 \mathrm{~mm}$. Above that, increasing the amount of irrigation has no significant effect on the crop yield (Fig. 7a). A similar relationship is observed between the WUE and the amount of irrigation (Fig. 7b). The WUE increases as the amount of irrigation increases, and then stayed

Table 5. Nitrogen balance under the traditional management practice (T1) and improved management practice (T2).

\begin{tabular}{|c|c|c|c|}
\hline & \multirow{2}{*}{$\mathrm{N}$ flux } & \multicolumn{2}{|c|}{ Treatment $\dagger$} \\
\hline & & $\mathrm{T} 1$ & $\mathrm{~T} 2$ \\
\hline \multirow[t]{4}{*}{ Input $\left(\mathrm{kg} \mathrm{N} \mathrm{ha}^{-1}\right)$} & Fertilizer & 179 & 317 \\
\hline & Atomspheric deposition & 28 & 28 \\
\hline & Irrigation & 235 & 180 \\
\hline & Net mineralization & 48 & 45 \\
\hline \multirow[t]{4}{*}{ Output (kg N ha-1) } & $\mathrm{NH}_{3}$ volatilization & 2 & 5 \\
\hline & Denitrification & 1.3 & 1.9 \\
\hline & Crop uptake & $\begin{array}{c}290 \\
(287 \pm 27)\end{array}$ & $\begin{array}{c}273 \\
(265 \pm 30)\end{array}$ \\
\hline & Leaching & 255 & 116 \\
\hline \multicolumn{2}{|l|}{ Balance (kg N ha ${ }^{-1}$ ) } & -59 & 112 \\
\hline \multicolumn{2}{|l|}{ Leaching factor‡ (\%) } & 58 & 21 \\
\hline \multicolumn{2}{|c|}{ Measured yield $\left(\mathrm{kg} \mathrm{ha}^{-1}\right)$} & 11,606 & 12,209 \\
\hline \multicolumn{2}{|l|}{ FNUE§ $\left(\mathrm{kg} \mathrm{kg}^{-1} \mathrm{~N}^{-1}\right)$} & 26 & 23 \\
\hline
\end{tabular}

†The number in parentheses is the measured value.

₹ Leaching factor $=$ leaching/total $\mathrm{N}$ input $\times 100$.

$\S$ FNUE, Fertilizer $\mathrm{N}$ use efficiency $=$ yield/total $\mathrm{N}$ input. at a constant level when the amount of irrigation exceeded $534 \mathrm{~mm}$. There is a separate group of data points that fall just below the linear part of the curve (Fig. $7 \mathrm{a}$ and $7 \mathrm{~b},<10,000 \mathrm{~kg}$ $\mathrm{ha}^{-1}$ yield and between 300 and $600 \mathrm{~mm}$ irrigation). The same amount of irrigation with fewer irrigation events led to greater water drainage and nitrate leaching, which may be the reason for that. Both water drainage and nitrate leaching increased sharply as the amount of irrigation increases (Fig. 7c and 7d). The data were fitted to a quadratic curve as:

$$
\left\{\begin{array}{c}
\mathrm{WD}=0.0007 I^{2}-0.4734 I+98.3 \\
\mathrm{NL}=0.0004 I^{2}-0.2589 I+51.9
\end{array}\right.
$$

where WD represents the water drainage $(\mathrm{mm})$ and NL represents the nitrate leaching $\left(\mathrm{kg} \mathrm{N} \mathrm{ha}^{-1}\right)$.

Under fixed amounts of irrigation, the crop yield, WUE, water drainage, and nitrate leaching were all affected by the irrigation events. Crop yield and WUE increased with irrigation events, following the linear with plateau model (Fig. 8a and $8 \mathrm{~b}$ ). Crop yield and WUE reached the maximum when irrigation was applied six times. Both water drainage and nitrate leaching showed a decreasing trend with increase of the number of irrigation events for a given amount of irrigation (Fig. 8c and 8d).

The crop demand for water and $\mathrm{N}$ at different growth stages are different: demand is low during the early crop growth stage, while it is very high during the later or critical growth stage. So it is very important to establish the BMPs of water and $\mathrm{N}$ based on crop needs. Sexton et al. (1996) optimized N and irrigation inputs for corn based on $\mathrm{N}$ leaching and yield on a coarse-textured soil, and found that nitrate leaching is reduced 30 to $40 \%$ by applying $\mathrm{N}$ at a rate that is $95 \%$ of maximum 

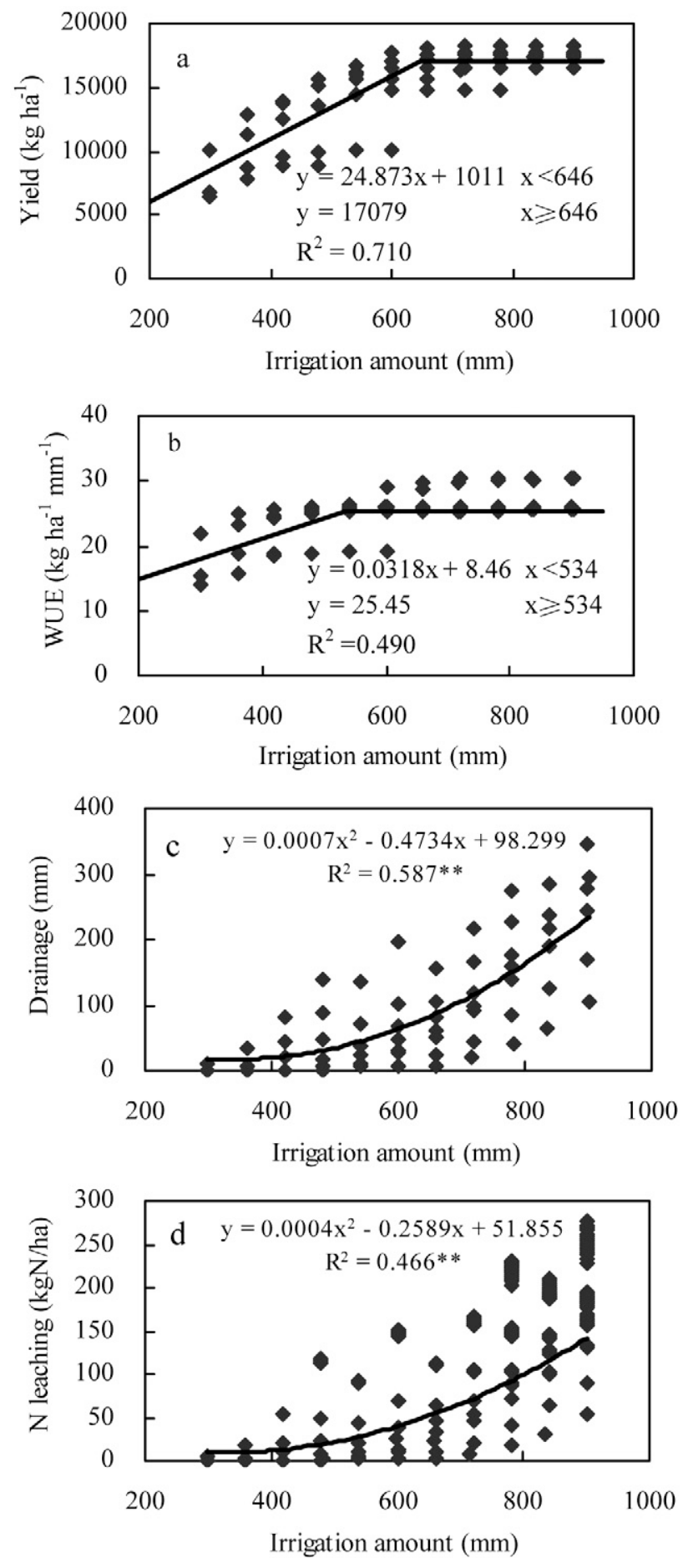

Fig. 7. The relationship between irrigation amount and (a) grain yield $\left(\mathrm{kg} \mathrm{ha}^{-1}\right)$, (b) water use efficiency (WUE; kg ha-1 $\mathrm{mm}^{-1}$ ), (c) drainage $(\mathrm{mm})$, and (d) nitrate leaching $\left(\mathrm{kg} \mathrm{N} \mathrm{ha}^{-1}\right)$.

yield from a 2-yr study, nitrate leaching can be reduced 50 to $55 \%$ by using a variable deficit trigger for irrigation scheduling. Gehl et al. (2005) pointed out efficient irrigation management and split $\mathrm{N}$ applications are important to minimizing nitrate leaching in irrigated cornfields. van Es et al. (2006) studied the effect of manure application timing, crop, and soil type on nitrate leaching, and found that nitrate leaching could be significantly reduced by split application in early and late spring or delaying manure application into the late fall. Our results also agreed with those findings.
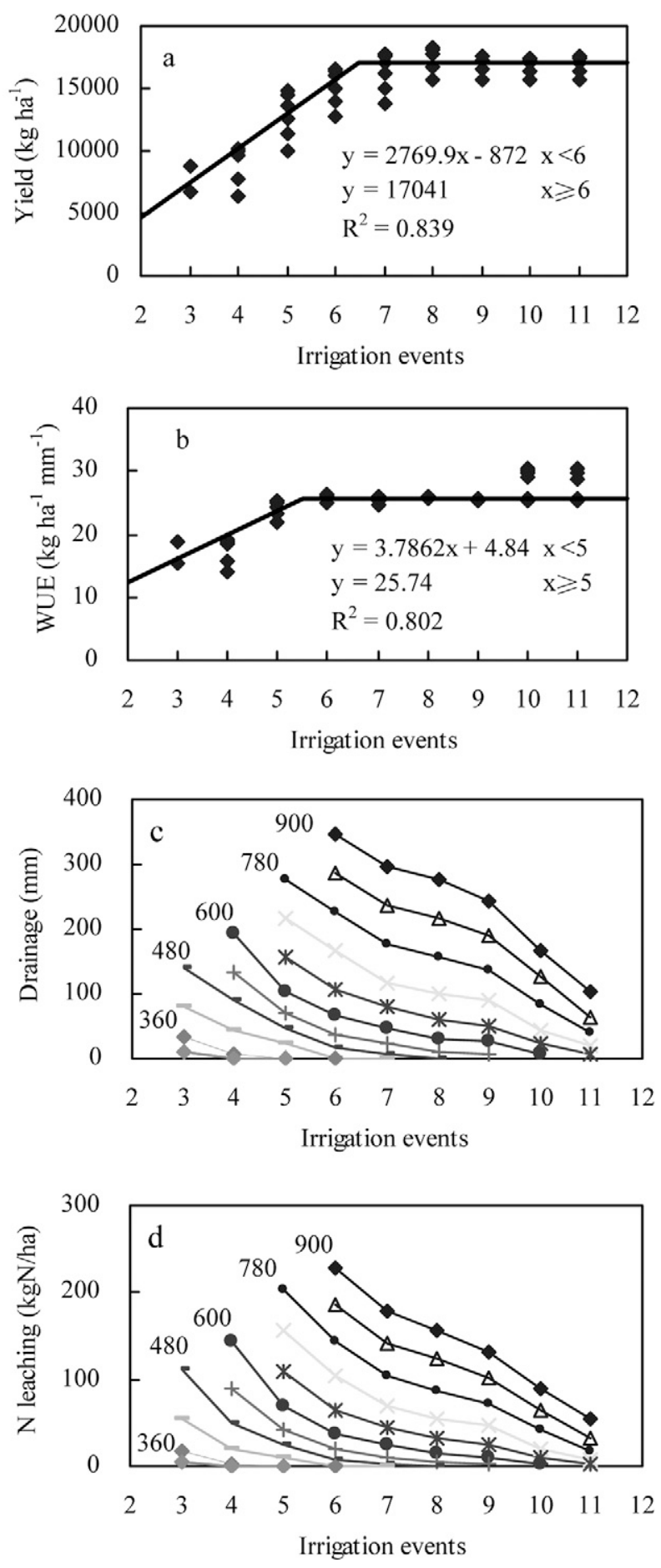

Fig. 8. The relationship between irrigation events and (a) grain yield $\left(\mathrm{kg} \mathrm{ha}^{-1}\right)$, (b) water use efficiency (WUE; $\mathrm{kg} \mathrm{ha}^{-1} \mathrm{~mm}^{-1}$ ), (c) drainage $(\mathrm{mm})$, and (d) nitrate leaching $\left(\mathrm{kg} \mathrm{N} \mathrm{ha}^{-1}\right)$.

In contrast to changing water management, the amount of fertilizer application and times were found to have limited effects on crop yields, WUE, water drainage, and nitrate leaching. This may be attributed to the fact that the minimal amount of fertilizer application $\left(75 \mathrm{~kg} \mathrm{~N} \mathrm{ha}^{-1}\right)$ already exceeds the crop growth demand because of the large amount of accumulated mineral $\mathrm{N}$ in the initial soil profile (about $360 \mathrm{~kg} \mathrm{~N}$ $\mathrm{ha}^{-1}$ ), and high nitrate concentrations in the irrigation water.

The model simulation results indicated that irrigation and fertilizer practices had significant effects on the crop yield, 
WUE, water drainage, and nitrate leaching. Quantitative analyses of the simulation outputs were conducted to obtain BMPs for water and $\mathrm{N}$ applications. The evaluation indices include crop yield, WUE, fertilizer $\mathrm{N}$ use efficiency (FNUE), and nitrate leaching. The weights for crop yield, WUE, FNUE, and nitrate leaching were set as $+5,+3,+2$, and -5 , respectively, to maximize the agricultural production and minimize the nitrate contamination of the groundwater. Results of the four evaluation indices from all the proposed scenarios are normalized with a range of 0 to 1 . Then an integrated index was calculated by summing the product of the normalized indices and their corresponding weights. Table 6 summarizes the evaluation results for some selected scenarios.

The treatment with $600-\mathrm{mm}$ irrigation input, four irrigation events, and $300 \mathrm{~kg} \mathrm{~N} \mathrm{ha}^{-1}$ fertilizer input had the lowest integral evaluation index. Under this scenario, the nitrate leaching is as high as $150.7 \mathrm{~kg} \mathrm{~N} \mathrm{ha}^{-1}$ and the crop yield only reaches $57 \%$ of the maximum. The FNUE is $20.8 \mathrm{~kg} \mathrm{~kg}^{-1} \mathrm{~N}^{-1}$. When the fertilizer application is reduced to single application at a rate of $75 \mathrm{~kg} \mathrm{~N} \mathrm{ha}^{-1}$ and the number of irrigations is increased to eight, the FNUE was significantly improved to $67.5 \mathrm{~kg} \mathrm{~kg}^{-1}$ $\mathrm{N}^{-1}$, while the WUE increases from 19.0 to $26.2 \mathrm{~kg} \mathrm{ha}^{-1} \mathrm{~mm}^{-1}$, and the crop yield reaches the maximum. This scenario had the highest integral evaluation index and may be used as the BMPs for maize in this region.

The results also indicate that the fertilizer application under Treatments T1 and T2 far exceed the crop requirements. Under the traditional management practice, too much water was applied. The field should be irrigated more frequently with less water.

The total irrigation area in the Chahantan oasis is 1876 ha. If the BMPs obtained here are applied, it would save about 4.2 $\times 10^{6} \mathrm{~m}^{3}$ of water and $118.2 \mathrm{t}$ of $\mathrm{N}$ fertilizer $\mathrm{yr}^{-1}$ compared with the traditional practice. It is significant for agricultural sustainable development in this desert oasis.

Those results were generated by the WNMM model based on a single year's data. The $75 \mathrm{~kg} \mathrm{~N} \mathrm{ha}^{-1} \mathrm{~N}$ fertilizer rate in the BMPs was obtained because of the high accumulated mineral $\mathrm{N}$ in the soil profile (about $360 \mathrm{~kg} \mathrm{~N} \mathrm{ha}^{-1}$ ), which was the same as the prevailing situation in the NCP (Ju et al., 2006; Fang et al., 2008). The mineral $\mathrm{N}$ in the soil profile will decrease with removal by crops. The decrease of mineral $\mathrm{N}$ in the soil profile should be taken into account for a long-term simulation. In addition, the BMPs for water and $\mathrm{N}$ obtained in this study were developed in an oasis with higher nitrate concentration in the groundwater. If in other areas, the nitrate concentration in the groundwater is lower, how to obtain the BMPs deserves further investigation.

\section{Conclusions}

A recently developed model (WNMM) was calibrated and validated under a single maize cropping system in desert oases. Soil water contents and nitrate concentrations in the soil profile, as well as crop growth simulated by the WNMM model, agreed well with the observed field data. We conclude that the WNMM model can be used to simulate the water movement and $\mathrm{N}$ transport as well as crop growth under situations prevailing at desert oases, and as a tool to optimize the water and $\mathrm{N}$ management.

Based on the crop uptake and nitrate leaching data, the estimated $\mathrm{N}$ loss by ammonia volatilization and denitrification was very low on sandy soils in desert oases. However, loss by nitrate leaching was very high. Under the traditional management practices, about $58 \%$ of total $\mathrm{N}$ input was leached out the $1.8-\mathrm{m}$ soil profile. Leaching from cropland is likely to be the main source of nitrate contamination in groundwater in Alxa. Crop yield, WUE, FNUE, and nitrate leaching were selected as evaluation criteria to identify the BMPs. It is concluded that the BMPs for maize production in the Chahantan oasis are to irrigate the croplands with $600 \mathrm{~mm}$ at a frequency of eight times per season, and to fertilize the soil at the rate of $75 \mathrm{~kg} \mathrm{~N}$ $\mathrm{ha}^{-1}$. Implementation of this BMP would reduce annual leaching of nitrate from approximately $255 \mathrm{~kg} \mathrm{~N} \mathrm{ha}^{-1}$, under current practices, to $14 \mathrm{~kg} \mathrm{~N} \mathrm{ha}^{-1}$ without reducing yields.

\section{Acknowledgments}

The study was funded by the National High-Tech Research and Development Program of China (2007AA10Z217), the National Key Basic Research Special Funds (2009CB118607), Non-profit Research Foundation for Agriculture (200803036), the China-Australia Cooperation Project ACIAR (Australia Centre for International Agricultural Research) (LWR/2003/039), and Program for New Century Excellent Talents in University (NCET-07-0809). We thank Dr. Debra Turner for providing the results of gaseous emissions. We

Table 6. Integrated evaluation index for different scenarios simulated by a water and nitrogen management model in Alxa League, Inner Mongolia, northwestern China.

\begin{tabular}{|c|c|c|c|c|c|c|c|c|}
\hline Total fert. $\dagger$ & Total irri. & No. irri. events & Yield & WUE & FNUE & $\mathrm{N}$ leached & Drainage & Integrated index \\
\hline $\mathrm{kg} \mathrm{N} \mathrm{ha}^{-1}$ & $\mathrm{~mm}$ & & $\mathrm{~kg} \mathrm{ha}^{-1}$ & $\mathrm{~kg} \mathrm{ha}^{-1} \mathrm{~mm}^{-1}$ & $\mathrm{~kg} \mathrm{~kg}^{-1} \mathrm{~N}^{-1}$ & $\mathrm{~kg} \mathrm{~N} \mathrm{ha}^{-1}$ & $\mathrm{~mm}$ & \\
\hline 300 & 600 & 4 & 10,103 & 18.99 & 20.75 & 150.73 & 195 & 2.79 \\
\hline 285 & 600 & 4 & 10,103 & 18.99 & 21.40 & 150.10 & 195 & 2.82 \\
\hline 270 & 600 & 4 & 10,103 & 18.99 & 22.11 & 149.41 & 195 & 2.85 \\
\hline 300 & 600 & 4 & 10,103 & 18.99 & 20.75 & 146.16 & 195 & 2.87 \\
\hline 255 & 600 & 4 & 10,103 & 18.99 & 22.86 & 148.67 & 195 & 2.89 \\
\hline 90 & 600 & 8 & 17,679 & 26.15 & 63.82 & 14.05 & 29 & 9.43 \\
\hline 75 & 660 & 10 & 16,465 & 29.83 & 59.25 & 9.66 & 24 & 9.47 \\
\hline 75 & 540 & 8 & 16,734 & 25.94 & 68.00 & 4.10 & 10 & 9.48 \\
\hline 75 & 720 & 10 & 17,138 & 30.39 & 58.33 & 20.09 & 43 & 9.49 \\
\hline 75 & 600 & 8 & 17,679 & 26.15 & 67.48 & 14.05 & 29 & 9.55 \\
\hline
\end{tabular}

† Fert., fertilizer; irri., irrigation; WUE, water use efficiency; FNUE, fertilizer N use efficiency. 
are grateful to Dr. Ian Willet for help with revising this manuscript. The authors are also grateful to the reviewers for their construct comments and revisions on this manuscript.

\section{References}

Ahuja, L.R., L.W. Ma, and T.A. Howell (ed.). 2002. Agricultural system models in field research and technology transfer. Lewis Publ., Boca Raton, FL.

Allen, R.G., L.S. Pereira, D. Raes, and M. Smith. 1998. Crop evapotranspiration: Guidelines for computing crop water requirements. FAO Irrigation and Drainage Pap. 56. Food and Agric. Organ. of the United Nations, Rome.

Arnold, J.G., B.A. Engel, and R. Srinivasan. 1993. A continuous time, grid cell watershed model. p. 267-278. In Proc. of Application of Advanced Information Technologies for the Management of Natural Resources. Sponsored by ASAE, Spokane, WA. 17-19 June 1993.

Asseng, S., I.R.P. Fillery, G.C. Anderson, P.J. Dolling, F.X. Dunin, and B.A. Keating. 1998. Use of the APSIM wheat model to predict yield, drainage and $\mathrm{NO}_{3}$ leaching in a deep sand. Aust. J. Agric. Res. 49:363-377.

Cai, G.X., D.L. Chen, H. Ding, A. Pacholski, X.H. Fan, and Z.L. Zhu. 2002. Nitrogen losses from fertilizers applied to maize, wheat and rice in the North China Plain. Nutr. Cycling Agroecosyst. 63:187-195.

Cameira, M.R., R.M. Fernando, and L.S. Pereira. 2003. Monitoring water and $\mathrm{NO}_{3}-\mathrm{N}$ in irrigated maize fields in the Sorraia Watershed, Portugal. Agric. Water Manage. 60:199-216.

Fang, Q., L.W. Ma, Q. Yu, R.W. Malone, S.A. Saseendran, and L.R. Ahuja. 2008. Modeling nitrogen and water management effects in a wheatmaize double-cropping system. J. Environ. Qual. 37:2232-2242.

Gehl, R.J., J.P. Schmidt, L.R. Stone, A.J. Schlegel, and G.A. Clark. 2005. In situ measurement of nitrate leaching implicate poor nitrogen and irrigation management on sandy soils. J. Environ. Qual. 34:2243-2254.

Hadas, A., B. Sagiv, and N. Haruvy. 1999. Agricultural practices, soil fertility management modes and resultant nitrogen leaching rates under semiarid conditions. Agric. Water Manage. 42:81-95.

Hansen, S. 2000. DAISY. Available at http://code.google.com/p/daisy-model/ (verified 11 Jan. 2010).

Hanson, J.D., K.W. Rojas, and M.J. Shaffer. 1999. Calibrating the root zone water quality model. Agron. J. 91:171-177.

Hu, K.L., Y.F. Huang, H. Li, B.G. Li, D.L. Chen, and R.E. White. 2005. Spatial variability of regional shallow groundwater level, EC, nitrate content and risk assessment of nitrate contamination. Environ. Int. 31:896-903.

Hu, K.L., B.G. Li, D.L. Chen, Y.P. Zhang, and R. Edis. 2008. Simulation of nitrate leaching under irrigated maize on sandy soil in desert oasis in Inner Mongolia, China. Agric. Water Manage. 95:1180-1188.

Hutson, J.L., and R.J. Wagenet. 1991. Simulating nitrogen dynamics in soils using a deterministic model. Soil Use Manage. 7:74-78.

Jones, J.W., G. Hoogenboom, C.H. Porter, K.J. Boote, W.D. Batchelor, L.A. Hunt, P.W. Wilkens, U. Singh, A.J. Gijsman, and J.T. Ritchie. 2003. The DSSAT cropping system model. Eur. J. Agron. 18:235-265.

Ju, X.T., C.L. Kou, F.S. Zhang, and P. Christie. 2006. Nitrogen balance and groundwater nitrate contamination: Comparison among three intensive cropping systems on the North China Plain. Environ. Pollut. 143:117-125.

Jury, W.A., and D.R. Nielsen. 1989. Nitrate transport and leaching mechanism. p. 139-157. In R.F. Follett (ed.) Nitrogen management and ground water protection. Elsevier, Amsterdam.

Leonard, R.A., W.G. Knisel, and D.S. Still. 1987. GLEAMS: Groundwater loading effects of agricultural management systems. Trans. ASAE 30:1403-1418.

Li, Y., D.L. Chen, Y.M. Zhang, R. Edis, and H. Ding. 2005. Comparison of three modeling approaches for simulating denitrification and nitrous oxide emissions from loam-textured arable soils. Global Biogeochem. Cycles 19:1-15.
Li, Y., R.E. White, D.L. Chen, J.B. Zhang, B.G. Li, Y.M. Zhang, Y.F. Huang, and R. Edis. 2007. A spatially referenced Water and Nitrogen Management Model (WNMM) for (irrigated) intensive cropping systems in the North China Plain. Ecol. Model. 203:395-423.

Ma, L.W., R.W. Malone, P. Heilman, D.B. Jaynes, L.R. Ahuja, S.A. Saseendran, R.S. Kanwar, and J.C. Ascough II. 2007. RZWQM simulated effects of crop rotation, tillage, and controlled drainage on crop yield and nitrate-N loss in drain flow. Geoderma 140:260-271.

Mack, U.D., K.H. Feger, Y. Gong, and K. Stahr. 2005. Soil water balance and nitrate leaching in winter wheat-summer maize double-cropping systems with different irrigation and $\mathrm{N}$ fertilization in the North China Plain. J. Plant Nutr. Soil Sci. 168:454-460.

Scotter, D.R., B.E. Clothier, and M.A. Turner. 1979. The soil water balance in a fragiaqualf and its effect on pasture growth in Central New Zealand. Aust. J. Soil Res. 17:455-465.

Sexton, B.T., J.F. Moncrief, C.J. Rosen, S.C. Gupta, and H.H. Cheng. 1996. Optimizing $\mathrm{N}$ and irrigation inputs for corn based on $\mathrm{N}$ leaching and yield on a coarse-textured soil. J. Environ. Qual. 25:982-992.

Shaffer, M.J., L.W. Ma, and S. Hansen. 2001. Modeling carbon and nitrogen dynamics for soil management. p. 55-72. CRC Press, Boca Raton, FL.

Shaffer, M.J., T.E. Schumacher, and C.L. Ego. 1995. NLEAP. http://www.ars. usda.gov/services/software/software.htm (verified 18 Jan. 2010).

Sogbedji, J.M., H.M. van Es, C.L. Yang, L.D. Geohring, and F.R. Magdoff. 2000. Nitrate leaching and $\mathrm{N}$ budget as affected by maize $\mathrm{N}$ fertilizer rate and soil type. J. Environ. Qual. 29:1813-1820.

Sun, B., D.L. Chen, Y. Li, and X.X. Wang. 2008. Nitrogen leaching in an upland cropping system on an acid soil in subtropical China: Lysimeter measurements and simulation. Nutr. Cycling Agroecosyst. 81:291-303.

van Es, H.M., J.M. Sogbedji, and R.R. Schindelbeck. 2006. Effect of manure application timing, crop, and soil type on nitrate leaching. J. Environ. Qual. 35:670-679.

van Genuchten, M.Th. 1987. A numerical model for water and solute movement in and below the root zone. Unpub. Research Rep. U.S. Salinity Lab., Riverside, CA.

Walvoord, A., F.M. Phillips, D.A. Stonestrom, R.D. Evans, P.C. Hartsough, B.D. Newman, and R.G. Striegl. 2003. A reservoir of nitrate beneath desert soils. Science 302:1021-1024.

Webster, C.P., M.A. Shepherd, K.W.T. Goulding, and E. Lord. 1993. Comparison between methods for measuring the leaching of mineral nitrogen from arable land. J. Soil Sci. 44:49-62.

Wilcke, W., and J. Lilienfein. 2005. Nutrient leaching in Oxisols under native and managed vegetation in Brazil. Soil Sci. Soc. Am. J. 69:1152-1161.

Williams, J.R. 1995. The EPIC model. p. 909-1000. In V.P. Singh (ed.) Computer models of watershed hydrology. Water Resources Publ., Highlands Ranch, CO.

Willmott, C.J. 1981. On the validation of models. Phys. Geogr. 2:184-194.

Zhang, W.L., Z.X. Tian, N. Zhang, and X. Li. 1996. Nitrate pollution of groundwater in northern China. Agric. Ecosyst. Environ. 59:223-231.

Zhang, Y.M., D.L. Chen, J.B. Zhang, R. Edis, C.S. Hu, and A.N. Zhu. 2004 Ammonia volatilization and denitrification loss from irrigated maizewheat rotation field in the North China Plain. Pedosphere 14:533-540.

Zhang, Y.S., Z.R. Yu, and P.M. Driessen. 2002. Experimental study of assimilate production, partitioning and translocation among plant organs in summer maize ( $Z$ ea $L$ mays) under various environmental and management conditions. Acta Agron. Sin. 28:104-109.

Zhu, Z.L., and D.L. Chen. 2002. Nitrogen fertilizer use in China-Contributions to food production, impacts on the environment and best management strategies. Nutr. Cycling Agroecosyst. 63:117-127.

Zotarelli, L., J.M. Scholberg, M.D. Dukes, and R.M. Carpena. 2007. Monitoring of nitrate leaching in sandy soils: Comparison of three methods. J. Environ. Qual. 36:953-962. 